\title{
How Engineering and Business Schools can benefit from Using Regionalization in a Globalized World-Insights from Kant and Chaos Theory
}

\author{
Carsten M. Syvertsen \\ Ostfold University College, Norway
}

\begin{abstract}
The purpose of the article is to show how Chinese engineering schools and business schools can benefit from using a regional approach in a globalized world. The objective is to achieve economic growth. In order to tailor make services to the needs of the students and the business community research can be the main activity of engineering schools and business schools, focusing on undergraduate programs, building the reasoning on insights from Kant and chaos theory. Graduate programs can to a greater extent use applied approaches suited to the needs of the business world and the world of science. It is suggested that a regional model is used building on technology, leadership and value creation in order to meet expected economic growth. The sample of schools is from Asia, Europe and America (USA).
\end{abstract}

Keywords: Chinese Engineering Schools and Business Schools, Regionalization, Globalization, Research Approach, Kant, Chaos theory

\section{Introduction}

Leading economics in the OECD area entered into a stage of flux as the financial crisis set in in 2008, leading to a recession that continues to this day. September 2008 marked a watershed in international affairs. The bankruptcy of Bear Sterns and Lehman Brothers triggered downsizing of business activities in many firms, with negative consequences for engineering schools and business schools as well.

At the same time China has become a major player in business and politics at the global scene. Large population is a clear advantage of China together with a good infrastructure, particularly in urban areas. China has a solid and proud history of international trade and the use of advanced technology, making a study of business schools and engineering schools interesting. Many believe that the growth potential of the Chinese market offers a unique possibility for the educational sector.

The Chinese economy showed signs of saturation in spring and summer 2015, with a major decline at the Shanghai Stock Exchange. However, we regard the long term perspectives as promising leading to the conclusion that a strong continual growth seems likely.

We link economic growth to research by linking research to regionalization in a globalized world. We are aware that a framework is lacking for organizing educational institutions involved in engineering and business-administration. We are of the opinion that the educational sector can be seen as being in a state of crisis, a crisis that can be understood as being caused by an increased tension between "base" and "superstructure", i.e. the ongoing work processes and the structures established to manage them. The changes in the "base" leading to tensions include a stronger emphasis on technology, leadership and value creating processes. Together these changes make the educational sector more complex and dynamic, which again makes the traditional "machine bureaucracy" (Mintzberg, 1979) model of organizing not as relevant as it once was.

International Journal of Management Science and Business Administration, vol. 2, issue 11, pp. 7-14, October 2016 
New patterns of competition threaten firm survival in virtually all industries. At the same time well-established management tools are no longer as relevant as they once were. For this reason it is crucial that new organizational models are erected, and that new applications are found for existing models.

In order to handle increased complexity and turbulence it is pertinent that the educational sector achieves a better understanding of how continuous entrepreneurship can support regionalization in a globalized world. We believe that entrepreneurship in the educational sector can take place in the interplay between technology, leadership and value creating processes. Technology can be regarded as an active change agent that can have consequences for ways educational institutions are organized. Technological solutions are becoming increasingly integrated with a focus on largescale integrated infrastructures. New technologies are constantly being developed while there is a lack of organizational models for how to organize innovations. New use of technologies may require novel forms of cross-disciplinary collaborations at odds with existing organizational structures. Technology can influence leadership, which both can have an influence on value-creating processes, i.e. economic growth. How Chinese engineering schools and business schools can organize themselves to meet future economic growth through a focus on research?

\section{Theoretical focus}

\subsection{Kant}

According to Kant (1992), undergraduate programs are the most important as they are the foundations of graduate programs due to their strong philosophical approach. Undergraduate programs can benefit from having a strong research approach. This means that it can be necessary to disregard, and even to overturn existing knowledge (Kuhn, 1970). Creating new knowledge requires theory building and conceptualization, experimentation and testing. The process of creating new knowledge also involves mistakes and dead ends, in accordance with the Plato's school (Goodlibe, 2000).

By putting research in the center of undergraduate programs, using broad research approaches can have consequences for the recruitment of professors. It can lead to openings for professors in other academic disciplines not usually regarded as mainstream, for example in history, medicine and theology. Professors with a stronger interest for, de facto, engineering and business situations can to a greater extent be involved in teaching at graduate levels. Graduate programs can benefit from serving the engineering and business community by focusing on the use of existing knowledge. Graduate programs can prepare students for a professional career, using applied research approaches and using executive experiences as benchmarks.

\subsection{Chaos theory}

The emerging conceptualization of reality is based on complex, dynamic, non-linear and unpredictable systems, often referred to as chaotic systems. Chaos describes a situation where a system is dislodged from its steady state condition by trigging events. It involves regrouping of elements of a given system, from which a new order eventually emerges (Fitzgerald and Eijnatten, 1998).

Complexity is related to the number and types of relations in a system (Rescher, 1998, 1). In case of a high degree of complexity, system behaviors will easily be perceived as being chaotic. The performance of a system is hard to explain based on how the various parts operate. From the moment of increased complexity in a system, subsequent expansion has a tendency to follow, i.e. complexity feeds on itself (Rescher, 1998, 6).

An edge of chaos exists when a system is in tenuous equilibrium. An analogy is borrowed from Waldrop (1992) explaining a pile of sand heaped on a table to the limit capacity. It implies a readiness for change, or "an edge of chaos" states in which the adhesive friction between the sand and grains are taxed to the limit of tolerability.

It is when a system is in a state of chaos that it is most vulnerable to the butterfly effect, which states to small causes can have large effects (Lorentz, 1963). This metaphor explains that a butterfly in Amazon can, of course theoretically, cause a swelling ripple that, in turn, can lead to a gigantic dust storm in Texas. However, Lorentz (1963) noted that some systems are likely to make "smoothing" adjustments so that "wild fluctuations" in the short term may be partially nullified in the long term through negative feedback mechanisms. 
Chaotic systems, such as educational institutions at the university and business school level have an ability of selforganization (Gleick, 1987). A chaotic system can be regarded as an adhesive friction between sand grains, taxed to the limit of their tolerability. It implies a critical point where a single grain dropped on a pile under maximum stress will cause a sudden phase shift into dramatic chaos manifested in the collapse of a face of the sand pile. Since this point of critically cannot be determined with exact prediction, it can be wise to have scenarios on hand as to how to respond.

\section{Foundations in methodology}

\subsection{Methodological position}

The methodological position is within the postmodern perspective. It also incorporates elements of the interpretive perspective. We assume that meaning is locally created, and that decision making is built on a decentralized framework (March, 1994) in accordance with principles found at engineering schools and business schools.

The decentralized framework fits well with the global trend in international business and politics. Economic turbulence coupled with accelerating internationalization, continuous improvements of technologies and deregulation of markets, at least in Europe and the US. This in turn leads to a need for organizational flexibility, more creative leadership practices and organizational models that pay increased attention to changing customer requirements.

The research in this paper is reported from a subjectivist or phenomenological paradigmatic point of view, as it seeks to explore the factors that can support research at undergraduate levels and more applied approaches at master degree levels. This holistic view implies that social phenomena are researched in totality in order to obtain a deep, rich and comprehensive insights and understandings of the phenomena being studied. A phenomenological inquiry implies that the study object is examined in its natural setting.

\subsection{A flexible research approach}

As the study processed, a similar process that outlined by Meyer et al (1993, 68), whereby concepts and research methods were constantly rethought and updated following analysis and findings, was followed. Similarly, Hinings and Greenwood $(1988,99)$ argued that the researcher has to modify theoretical frameworks during the life of the project. It has been recognized that the conventional research cycle-conceptualization, design, measurement, analysis and reporting, does not hold well in hyperturbulent environments (Chiaburu, 2006, 744). This "interactive approach" (Orton, 1997) is considered a flexible research approach since "numerous trade-offs are required" in order to "learn about variety of ways in which organizational designs, contexts, and leaders can affect how and when different types of change occur" (Glink et al, 1990: 310). In order to understand organizational phenomena at a more than superficial level, the scholarly literature has called for a more in-depth process research (Langley, 1999).

In our research we consider change to be a continual process of becoming, rather than a succession of stable states. This viewpoint suggests that social reality is not a steady state, but rather can be regarded as a dynamic process (Beech and Johnson, 2005). Thus, there is a need to observe events and interactions as they unfold over time. This approach suggests that dynamic construction, deconstruction and reconstruction of meaning make sense over time as contextual forces evolve and as organizational restructuring takes place.

An interpretive approach is regarded as suitable for the investigation of complex and poorly understood phenomena (Dixon et al, 2007) since such an approach implies that the researcher's task is to "make sense of local actors' activities" (Soulsby and Clark, 2007, 1426). Thus, the important criterion for assessing interpretive data analysis is its ability to provide reasonable insights into phenomena that demand deeper understandings. Empirical findings illustrate, rather than validate, the theories they reflect (Astley and Zammuto, 1992). This implies that interpretive approaches are closely linked to qualitative methodologies, which are particularly useful when examining change processes in organizations (Gummersson, 2000).

\subsection{Qualitative research approaches}

Qualitative methodology is in itself an appropriate and adequate methodology for building theory in a particular area of inquiry. Qualitative data can even be superior to quantitative data in depth, density and vividness of information, all of 


\section{Carsten M.Syvertsen}

How Engineering and Business Schools can benefit from Using Regionalization in a Globalized World-Insights from Kant and Chaos Theory

which are characteristics of holistic organizations (Roach, 1992). Daft (1983) is of the opinion that human senses are necessary to interpret organizational phenomena and discovering new knowledge. Daft and Lewin (1993) are in favor of a new approach in the development of organizational theory:

"We believe that at this stage of theory development, research on new forms of organizations require a new approach, quite different from research typically published in academic journals. This work will be characterized by midrange theory and method, grounded research, and research that does not presume to test hypotheses empirically".

We collected data through data analysis and secondary sources. The primary source was document analysis. Documents were prepared for personal rather than official reasons and include diaries, memos, letters, field notes, and so on (Lincoln and Guba, 1985, p. 277).

Documents, closer to speech, require more conceptual interpretation (Hodder, 2000). Just as qualitative research is "endlessly creative and interpretative" (Denzin and Lincoln, 2005), qualitative researchers find them in a position of having to be endlessly creative and interpretive with respect of the spaces they move in and out of as they conceptualize, conduct, write and report their research (Cheek, 2006).

We faced a number of dilemmas but managed to gain insights by contacting key persons at engineering schools and business schools in Asia, Europe and America (the US).

We contacted key persons of five business schools and five engineering schools in Europe and two business schools and two engineering schools in the USA. The author has studied at three of these institutions, two in Europe and one in the USA, keeping in contact with key persons for decades. The key persons got interested in the research and sent me information by mail. I know two business schools in China and two engineering schools. At one of the business school I had an old friend with whom I studied together at a doctoral program in Europe. He helped to pass my research questions to other key persons in China. This made it possible to pass the results from three continents. The research took about 18 months to complete, starting in January 2015 and finishing in June 2016.

Data analysis. As is typical in inductive research, we analyzed the data by first building case studies. We regarded each engineering school and business school as a case. I then compared findings across cases for the purpose of constructing a conceptual framework (Eisenhardt, 1989). I noted differences and similarities between cases. We waited for further analysis until we had completed all case write-ups to maintain a clear logic.

Once the individual case studies were complete, we used cross-case analysis, relying on methods suggested by Brown and Eisenhardt (1997), Eisenhardt (1989) and Miles and Huberman (1994) in order to develop conceptual insights. We created tables and graphs to facilitate comparisons and to develop a theoretical logic. We took several breaks during the analysis to refresh our thinking. The process took about one and a half year leading to the results that follow.

\section{Findings}

The economic geography of the post-industrialized world is characterized by fundamental processes of restructuring, an increased mobility of capital and a pursuit for new economic growth activities, particularly in the service sector. Traditional means of investing, conducting marketing ad work within political networks have underdone dramatic changes. In recent years, the service sector has become more important worldwide, for example when it comes to consumer preferences, wealth mobility and location mobility (Hudson, 1995). We believe that the same argument holds in the educational sector as a part of the service economy.

\subsection{Technological routines}

Based on data from secondary sources, our findings suggests that change in routines through the use of technological knowledge is the main change agent in transformation processes, being more radical than simply stating that technology simply can make organizational practices more effective (Barney, 1986, Orlikowski, 1993, 2000; Szulanski, 2000).

When routines change as a result of the use of technology, it has often been argued that the effects are greatest when 
professionals work closely together (Orlikowski, 1993). This also involves learning different role (Orlikowski, 2000), making numerous small adjustments to facilitate technology implementation.

Technology implementation often requires experimentation, using trial and error as means to find satisfactorily solutions (Thomke, 1998). Thus, psychological safety by taking risk without fear of material or reputation harm can facilitate collective learning in technology implementation processes (Orlikowski, 2000).

Our findings so far in the research project support such viewpoints, however in a more practical way than often highlighted in the business literature. Personal relationships are critical to get things done. Such relationships can serve as points of resolving conflicts, discussing future developments, guiding interactions, and enhancing information flows.

\subsection{Leadership}

It is reason to believe that business leaders have higher profiles than ever before. Leaders can hold a particular cognitive framework about a technology that is likely to affect leaders' perception of the meaning and the implication of a given technology (Edmondson, 1999).

\subsection{Value creation}

The process of creative destruction, facilitated by episodic witches in technical regimes, was positioned by Schumpeter (1942) to be the key endogenous driver of economic growth. Recently, several studies have linked measures of regional entrepreneurial activity to regional economic growth (e.g. Audretsch and Fritsch, 2002; Acs and Armington, 2004).

\section{Discussion-movements towards the business federation?}

Increased turbulence and complexity means that it is of vital importance that firms identify and explore business opportunities by taking an entrepreneurial strategic posture, building on strong performance incentives. Being entrepreneurial allows a firm to be responsive to lucrative market opportunities. An entrepreneurial strategic posture can give advantages by responding quickly to business opportunities at the same time as firms can be able to repress business threats. Being agile evolves staying nimble and flexible, open to new evidence, ready to reassess past choices and change direction as business opportunities are explored and exploited.

Handy $(1992,1994)$ expends the nature of contradictions that managers face to issues related to power and control. He adds that a major challenge for modern businesses is to try to achieve the advantages of large firms as well as small ones. Handy is of the opinion that the federalist concept, applied in a business context, is particularly appropriate to deal with managerial contradictions. A company that seeks growth can emphasize an organizational model that tries to solve the dilemma of operating locally within an international network. The dilemma should be in accordance with the times we live in. We wish to be a part of a strong entity at the same time as we prefer a high degree of autonomy in our professional lives. Within the business federation it is not top management that delegates to local units but rather local units that give top management the permission to handle certain tasks because they are handled more efficient at the top, for example when introducing corporate support services. The center does not direct or control, but rather advices, coordinates and influences, being well aware that initiatives generally come from the local levels.

A number of management thinkers and researchers advocate a process of renewal of corporations which inevitably will lead them to behave in accordance with federalist principles (Simon et al, 1950; Drucker, 1954; March and Simon, 1958; Provan, 1983; Barlett and Ghoshal, 1988; Bartlett and Ghoshal, 1995; Handy, 1992; Handy, 1994; Syvertsen, 2000). However, these authors only provide a partial understanding of the importance of federalist behavior. We describe federalist behavior through the use of a building block system consisting of autonomy at local levels, the extent to which local offices share resources, ownership of resources at local levels, lack for hierarchical control of local units, and how corporate services can be used. The building block system represents a guide for how to hold businesses within Senegal together.

Autonomy. It is often assumed that autonomy can promote entrepreneurial activities. This argument can also be used in studies of the business federation since autonomy can influence entrepreneurial processes. The relationship between autonomy and performance is assumed to be positive since local levels may serve clients in a better way than the corporate 


\section{Carsten M.Syvertsen}

How Engineering and Business Schools can benefit from Using Regionalization in a Globalized World-Insights from Kant and Chaos Theory

level can. We believe that this argument will hold in studies of businesses. Traditionally the society has been based on agriculture with a strong degree of autonomy for each farm.

Ownership. It is believed that ownership over traditional means of production and intangible resources such as knowledge will have a positive effect on economic growth within regions in Senegal. Giving women a high degree of responsibility will lead to economic growth according to our reasoning (see for example initiatives in micro finance leading to regional growth in selected areas of Africa, to mention just one example).

Resource sharing/interdependence. Firms face challenges in providing local offices with access to limited resources without duplicating costs. This requires specialization and coordinated efforts among local offices as individuals and companies are constantly moving toward more tailor make solutions. A positive relationship between resource sharing and economic performance can be expected.

Control mechanisms. Social means of control, consisting of ideology, culture and sanctions, can regulate behaviors at local levels within the business federation. By ideology we mean integrated set of beliefs that unite a firm so that members are ensured basic knowledge on how a firm is supposed to work. Culture can be regarded as cognitive mindsets, manifested through behaviors and language. Sanctions can involve that group members punish colleagues who violate goals, norms and values, ranging from gossips and rumors to ostracism and sabotage (Ferlie and Pettigrew, 1996). Social means of control are supposed to have a positive effect on performance.

\section{Conclusion}

We illustrate how engineering schools and business schools can use a regional approach in a globalized world, aiming for economic growth. We show that technology and leadership can have an influence on value creation. We regard technology as the main change agent. A focus on technology can also have a positive effect on communication among actors in the business community and in the public sector. At first stage businesses within regions will probably use knowledge on a trial-and-error basis using technology to change routines. In the longer run changes in routines are assumed to lead to strategic change leading to economic growth. More research is necessary to find out more about how actors can co-operate in networks, paying attention to routines. A global focus means that intangible resources become more important moving to a broader approach involving more than economic parameters. Value creation should also have a broad approach involving social as well as economic parameters.

\section{References}

- Acs, Z.J. and Arminton, C. (2004), Employment, growth and entrepreneurial activities in cities, Regional Studies, 38, 911-927, CrossRef

- Astley, W.G. and Zammuto, R.F. (1992), Organization Science, Managers and Language Games, Organization Science, 3(4), 443-460, CrossRef

- Audtretsch, D.B. and Fritsch, M. (2002), Growth regimes over time and space, Regional Studies, 36, 113-124, CrossRef

- Ariwa, E. and Syvertsen, C.M. (2010), Green Digital Enterprise and Chaos Theory in Tourism Development: The Case of Eco-Tourism in South Africa, International Journal of Green Computing, 1(1), 40.52, January-June.

- Ariwa, E. and Syvertsen, C.M. (2010), Information of Economic Growth in the Health-tourism Industry in Montenegro Using Insights from Regionalization. Journal of Internet Banking and Commerce, April, Vol. 15, no.1, 1-14.

- Barney, G. (1986), Technology as an occasion for structuring: Evidence from observations of CT scanners and the social order of radiology departments, Administrative Science Quarterly, 20, 160-176.

- Barlett, C.A. and Ghoshal, S. (1988), Managing Across Borders: The Transnational Solution, Cambridge, Mass: Harvard Business School Press.

- Barlett, C.A. and Ghoshal, S. (1995), Transnational Management: Text, Cases and Readings in Cross-Border Management (2nd ed.), Chicago: Irwin. 


\section{Carsten M.Syvertsen}

How Engineering and Business Schools can benefit from Using Regionalization in a Globalized World-Insights from Kant and Chaos Theory

- Beech, N. and Johnson, P. (2005), Discourses of Disputed Identities in the Practice of Strategic Change. The Mayor, the Street-fighter and the Insider-out, Journal of Organizational Change Management, 18(1), 31-47, CrossRef

- Brown, S.L. and Eisenhardt, K.M, (1997) The Art of Continuous Change: Linking Complexity and Time-paced Evolution in Relentlessly Shifting Organizations", Administrative Science Quarterly, 42, 1-34. Cheek, J. (2006), Qualitative Inquiry, ethics and the politics of evidence: Working within these spaces rather than being worked over by them", Second International Congress of Qualitative Inquiry, University of Illinois at Urbana-Champaign, May 4-6.

- Chiaburu, D.S. (2006), Managing organizational change in transition economics, Journal of Organizational Change Management, 19(6), 738-746, CrossRef

- Clandinin, D.J. and Connelly, F.M. (1999), Narrative inquiry: Experience and story in qualitative research, San Francisco: Jossey-Bass.

- Daft, R. (1983), Learning the craft of organizational research, Academy of Management Review 8 (4), 539-46,

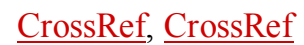

- Daft, R, and Lewin, A.Y, Where are the theories for the "new" organizational forms? An editorial essay, Organization Science, 1 (1), 1-10, CrossRef

- Densin, N, and Lincoln, IYS (2005), "Preface" in N Denzin and YS Lincoln (eds), The Sage Handbook of Qualitative Research, (3rdedn), Sage Publications, Thousand Oaks.

- Dixon, S., Meyerm K.E. and Day, M. (2007), Exploitation and Exploration Learning and the Development of Organizational Capabilities: A cross-case Analysis of the Russian Oil Industry, Human Relations. 60(10), 1493-1523, CrossRef

- Drucker, P. (1954), The Practice Management, New York: Harper and Row.

- Eisenhardt, K.E. (1989), Building theories from case study research, Academy of Management Review, 14, 488-511, CrossRef, $\underline{\text { CrossRef }}$

- Emondson, A.C. (1999), Psychological safety and learning behavior in work teams, Administrative Science Quarterly, 44, 359-383.

- Ferlie, E. and Pettigrew, A.M. (1996), Managing through networks: some issues and implications for the NHS, British Journal of Management, 7(1), 81-99, CrossRef

- Gleick, W.H., Huber, C.P. Miller, C.C., Doty, H.D. and Sutcliffe, K.M. (1990), Studying changes in organizational design and effectiveness. Retrospective event histories and periodic assessments, Organization Science, 1(3), 293-312, CrossRef

- Grant, R.M. (1996a), Propering in dynamically competitive environments: organizational capability as knowledge integration, Organizational Science, 7(4), 375-387, CrossRef

- Grant, R.M. (1996b), Towards a knowledge-based theory of the firm, Strategic Management Journal, 17 (Winter Special Issue), 109-122.

- Gunnersson, E. (2000), Qualitative Methods in Management Research, Sage Publications, Thousand Oaks, CA,

- Handy, C. (1992), Balancing corporate power: a new federalist paper, Harvard Business Review, 70(6), 59-72.

- Handy, C. (1994), The Age of Paradox, Cambridge, Mass: Harvard Business School Press.

- Hindings, C.R. and Greenwood, R. (1988), The Dynamics of Strategic Change, Oxford: Basel Blackwell. .

- Hooper, I. (2000), The interpretation of documents and the material culture, chapter 26, in

- Langley, A. (1999), Strategies or Theorizing from Process Data, Academy of Management Review, 24 (49), 691-710, CrossRef, CrossRef

- Leonard-Barton, D. (1995), Wellsprings of Knowledge: Building and Sustaining the Sources of Innovation, Boston, MA, Harvard Business School Press.

- Lincoln, Y.S. and Guba, E.G. (1985), Naturalistic Inquiry, Sage, Beverly Hills, CA.

- March, J.G, and Simon, H.A. (1958), Organizations, New York: John-Wiley and Sons.

- Meyer, A.D., Goes, J.B. and Brooks, G.R. (1993), Organizations Reachting to Hyperturbulence. In Huber, C.P. and Glink, W.H. (eds), Organizational Change and Redesign: Ideas and Insights for Improving Performance, Oxford: Oxford University Press.

- Miles, M.B and Hubeman, A.M. (1994), Qualitative data analysis, Thousand Oaks, CA, Neu, W.A. and Brown, S.W. (2008), Forming successful business-to-business services in goods-dominant forms, Journal of Service Research, 8(1), 3-17.

- Nonaka, I. and Takeuchi, H. (1995), The Knowledge Creating Company, Oxford:Oxford University Press. 


\section{Carsten M.Syvertsen}

How Engineering and Business Schools can benefit from Using Regionalization in a Globalized World-Insights from Kant and Chaos Theory

- Orlikowski, W.J. (1993), Learning from notes: Organizational issues in groupware implementation, Information Society, 9, 237-250, CrossRef

- Orlikowski, W.J. (2000), Using technology and constitution structures: A practice lens for studying technology in organizations, Organization Science, 11, 404-428, CrossRef

- Orten, J.D. (1997), From Inductive to Iteractive Grounded Theory: Zipping the Gap between Process Theory and Process Data, Scandinavian Journal of Management, 13(4), 419-438, CrossRef

- Provan, K.G. (1983), The federation as an interorganizational linkage network, Academy of Management Review, 1, 79-89, CrossRef, CrossRef

- Roach, T.W. (1992), Effective systems development in complex organizations: A field study of systems development and the use in United States Army Medical Department, Unpublished Doctoral Dissertation, University of Texas, Austin, Austin, TX.

- Soulsby, A. and Clark, E. (2007), Organization Theory and the Post-socialist Transformation: Contributions to Organizational Knowledge, Human Relations, 60(10), 1419-1442, CrossRef

- Szulanski, G. (2000), The process of knowledge transfers: A diachronic analysis of stickiness, Organizational Behavior and Human Decision Processes, 82, 9-27, CrossRef

- Syvertsen, C.M. (2000), Towards the business federation in management consulting firms, Doctoral thesis IESE Business School, University of Navarra, Barcelona.

- Syvertsen, C.M. (2012), Towards the business federation in top management consulting in top management consultingthe role of co-creaton, International Business Research, Vol. 5, No. 3, March.

- Syvertsen, C.M. (2012), Towards spiritual entrepreneurship in ecotourism in Southern Africa, International Business Research, Vol. 5, No. 2.

- Syvertsen, C.M. (2012), The rise and fall of the Anglo-Norwegian natural ice trade (1850-1914), Beta, nr. 1, 80-92.

- Wallin-Weihe, H-J. og Syvertsen, C.M. (2009), Utvikling av kultur som en strategisk kraft-et konseptuelt bidrag sett fra et kunnskapsperspektiv, Magma, no. 9.

- Wallin-Weihe, H.-J. og Syvertsen, C.M. (2009), Identity, Understanding, Memory, Landscape, Hertervig Akademisk, Stavanger (Norway). 